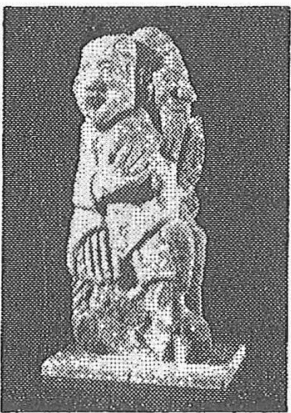

カット二石人像（重文） 奈良国立文化財研究所

1. は じめに

表面エネルギーは，表面（面積 $A$ ) が存在すること による自由エネルギー $(F)$ の増分 $\gamma=(\partial F / \partial A)_{T, V, N}$ である。（ $T, V ， N$ はそれぞれ温度，体積および分 子数)，この過剩エネルギーをできるだけ小さくする たわに，液体では表面積を小さくする方向に表面張力 が㗢く、それにさからって単位面積を広げるに要する 仕事 $\left(\mathrm{erg} \cdot \mathrm{cm}^{-2}=\mathrm{dyn} \cdot \mathrm{cm}^{-1}=10^{-3} \mathrm{~N} / \mathrm{m}\right)$ が $\gamma$ であ る。

高分子の表面エネルギーは，接着，ぬれ，印刷，分 散系の安定性, 生体適合性などの界面現象と直接に関 係する. 本稿はこれらの問題に基礎的知見を提供する ことを目的とし, はじめに高分子メルトの表面張力に ついて述べ, 高分子固体の表面エネルギーの評価法に 及ぶ。

\section{2. 高分子メルトの表面張力}

この 15 年ほどの間に, 多数の高分子について表面

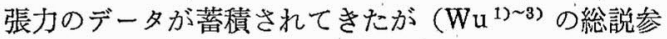
照), 分子量依存性索除いては, 分子構造などとの関 連を系統的に研究した例は少ない。ここではその問題 を比較的系統的に扱った筆者らの研究結果をむとにし 亡, 分子量依存性と高分子構造の効果を中心にして述 ベる. 高分子メルトの表面張力測定法として今日国際 的に推奨されているのは静泡法と䀣滴法で, その詳細 は近刊予定の成書4)にゆずる。

\section{2-1. 表面張力の分子量依存性}

高分子同族体の表面張力は主としてオリゴマー領域 で分子量 $(M)$ 依存性を示し, 批よ去 $\gamma=\gamma_{\infty}+A / M$ に従う（ $\gamma_{\infty}$ は $M \rightarrow \infty$ のときの表面張力, $A$ 注同族 列によって異なる正または負の定数).この関係は Sugden の式（1）加出発して, 次のように定式化

Surface Energy of Polymers

\section{高分子の表面 エネルギー}

\section{畑 敏雄}

Toshio Hata，接着剂研究所

することができる5),6)

$$
\begin{aligned}
\gamma & =\left\{\frac{\left(\rho_{L}-\rho_{G}\right) P}{M}\right\}^{\beta}=\left(\frac{\rho_{L} P}{M}\right)^{\beta} \\
& =\left(\frac{P}{V}\right)^{\beta}
\end{aligned}
$$

ここで $\rho_{L}, \rho_{G}$ は，それぞれ液体拉よび気体状態の密 度で高分子では $\rho_{G}$ を無視する.P はパラコール， $V$ は分子容， $\beta$ は MacLeod 指数之呼ばれるもので Sugden の場合 4 と括かれた， $P$ と $V$ には加成性が 成立するのでこれらをそれぞれ繰り返し単位（添字 $r$ ）と末端基（添字 $e$ ）の寄与匹分けると,

$$
\gamma=\left(\frac{m P_{r}+2 P_{e}}{m V_{r}+2 V_{e}}\right)^{\beta}
$$

mは繰返し単位の数で,ここでは両末端が等しい場合 を考えている.この式の変形によって次の（3）式が 得られ，※た指数展開之高次項の省略によって（4) 式の近似式が得られる.

$$
\begin{aligned}
& \gamma^{1 / \beta}=\gamma_{r}^{1 / \beta}+\frac{2 k}{m+2 k}\left(\gamma_{e}^{1 / \beta}-\gamma_{r}^{1 / \beta}\right) \\
& \gamma \simeq \gamma_{r}\left[1+\frac{2 \beta k}{m+2}\left\{\left(\frac{\gamma_{e}}{\gamma_{r}}\right)^{1 / \beta}-1\right\}\right]
\end{aligned}
$$

ここで $\gamma_{r}=\left(P_{r} / V_{r}\right)^{1 / \beta}, \quad \gamma_{e}=\left(P_{e} / V_{e}\right)^{1 / \beta}, \quad k=V_{e} / V_{r}$ で, $\gamma_{r}$ は $m \rightarrow \infty(M \rightarrow \infty)$ のときの $\gamma_{\infty}$ に等しい. $m+2$ は多くの場合重合度 $n$ と特忷るので，（4）式 は, $\beta$ が定数であれば（あるいは式中の 2 つの $\beta$ が 効果を相殺しあ党ば)， $\gamma$ が $1 / n$ または $1 / M$ に対

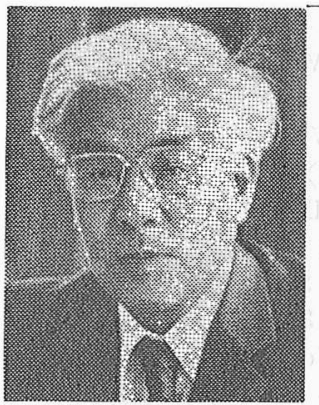

烟 敏雄 接着剂研究所 (101 東京都千代田区内神田 1-1510) 所長. 工博

昭和 15 年東京工業大学卒. 17 年 48 年東工大, 48 年 56 年 群馬大 (5ち 50 年 56 年学長) 東工大·群馬大名誉教授. 專門 は高分子界面化学, レオ口ジ 一, 接着科学. 著書に「複合材 料」東大出版会 (1975), 「接着 ハンドブック」日刊工業新聞社 (1980).

〈趣味〉 古代史散歩. 


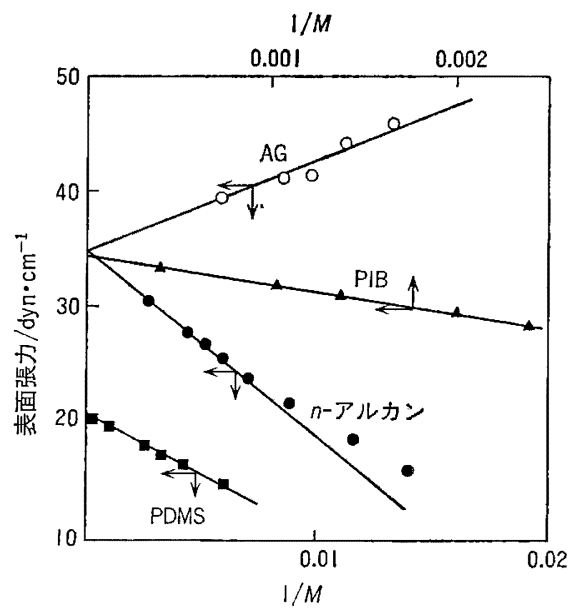

$\mathrm{AG}:$ アルキレングリコール $\left(20^{\circ} \mathrm{C}\right), \mathrm{PIB}:$ ポ

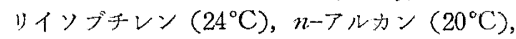
PDMS : ポリジメチルシロキサン $\left(25^{\circ} \mathrm{C}\right)$

図 1 表面張力の分子量 $(M)$ 依存性

して直線となることを示す 図 1 はとの例で, $n$ ーアル カンの低分子量域で，直線からはずれるのは，(4) 式の高次項の省略に主な理由がある.

(3)，(4) 式のどららの式によっても， $\gamma_{r} \gamma_{e} に$ 従って， $M$ の増大ととあに $\gamma$ は矢れぞれ増大 $(>)$, 減少（<）西いは不変（）となり, その穾例子と れそれ報告されている。

rの分子量依存性については, 畑の提案に続いて次 の諸式が提出された $\left(M_{n}\right.$ は数平均分子量).

LeGrand \& Gaines Jr. ${ }^{72}$ (1969)

$$
\begin{gathered}
r=\gamma_{\infty}-\frac{B}{M^{2 / 3}} \\
\mathrm{Wu}^{1)} \text { (1974) } \gamma^{-1 / 4}=\gamma_{\infty}{ }^{-1 / 4}+\frac{C}{M_{n}} \\
\mathrm{Wu}^{2)} \text { (1978) } \gamma^{1 / 4}=\gamma_{\infty}{ }^{1 / 4}-\frac{D}{M_{n}}
\end{gathered}
$$

LeGrand らの (5) 式は理論に裏つけられたもので はないが実験值をよく再現する．Wuの（6)，(7) 式は畑の誘導と全く同様のもので（3）式で $\beta=4$, $k=1$ と执いた近似式である.Wu はこれらの3つの 式が同じ程度の精度で実験結果をよく表わすと述べ, LeGrand $5^{8)}$ は $n$ アルカンの文献値を用いて自分の 式の優位性を主張し，とくに低分子量域で正確である といら。しかし（5）（7）式にはそれぞれ次のよう な問題がある.

一つは Wu の式の $\beta=4, k=1$ という近似の問題 である. $\beta$ は同族列や分子量によっても異なり，その 差の大きい場合には $5 \sim 3$ と変化する: $k\left(=V_{e} / V_{r}\right)$ の值も繰り返し単位と末端機の構造に大きな差があれ

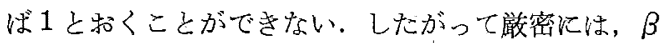

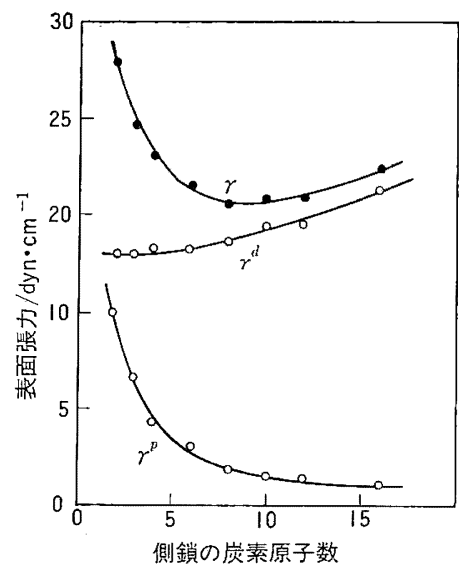

$\left(\gamma^{d}:\right.$ 分散力成分, $\gamma^{p}:$ 極性力成分)

図 2 ポリビニルアルキレートの表面張力 $\left(150^{\circ} \mathrm{C}\right)$ の側鎖長による変化

も $k$ も実測值を用いて，(3) 式による $\gamma^{1 / \beta} \sim k /(m+$ 2k）のプロットをすることが必要である. $\beta$ は（1） 式に従って $\log \gamma \sim \log \rho$ のプロットから得られるし， $k$ 正此容の分子量依存性から求められる. このように して（3）式を用いれば図 1 で直線からはずれた低分 子量域の $n$-アルカンるるくく直線にのる.

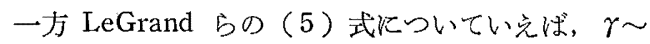
$M^{-2 / 3}$ の直線性は測定範囲ではよく成立するが， $M \rightarrow$ のの極值 $\gamma_{\infty}$ が，末端基だけを異にする同族体で異 なる值をとるといら問題がある。たと㐫ば $n$ ーアルカ ンとアルキレングリコールは，メチレン基の数が増大 して末端基が無視できる極限に招いて同じ $\gamma_{\infty}$ (ポリ エチレンに相当する）を示すべきだと思われるのに，

(5) 式のプロットまたは計算值によれば, nーアルカ

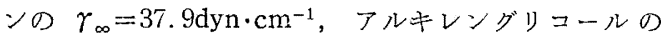
$\gamma_{\infty}=30.8 \mathrm{dyn} \cdot \mathrm{cm}^{-1}$ (いずれも $20^{\circ} \mathrm{C}$ ) と大きな差が ある.（3）式によるわれわれの場合, 前者は 35.3 $\mathrm{dyn} \cdot \mathrm{cm}^{-1}$, 後者は $35.6 \mathrm{dyn} \cdot \mathrm{cm}^{-1}$ と一致し, ポリエ チレンとも等しい，同様の例はポリエチレングリュー ルとその片末端メチル化物，掠よび両末端メチル化物 についても見られ，(5) 式ではそれぞれ $\gamma_{\infty}=42.4$, $44.1,44.5 \mathrm{dyn} \cdot \mathrm{cm}^{-1}\left(25^{\circ} \mathrm{C}\right)$ と差があるがわれわれの 式では 3 種の同族体はいずれも $\gamma_{\infty}=42.7 \mathrm{dyn} \cdot \mathrm{cm}^{-1}$ に収束する. この問題については，LeGrand-Gaines 式の理論的根拠にまでさかのぼって検討する必要があ る(この項の数值は紬村 ${ }^{9)}$ にる).

\section{2-2. 高分子構造と表面張力}

ここでは，一本の高分子鎖を特徵づける構造，すな わち立体規則性, 連鎖長とその分布, 分汥構造, 側鎖 長などの高分子的構造の表面張力に及ぼす効果につい て述べる。このらら立体規則性については，at-ポリ 


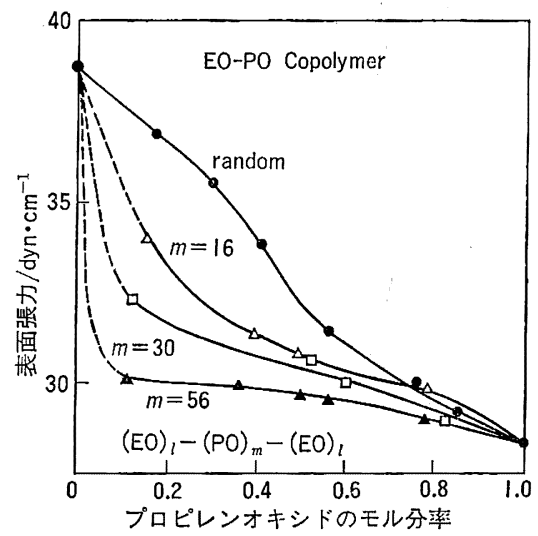

図 3 エチレンオキシド・プロピレンオキシド・ラ ンダム共重合体とブロック共重合体の表面張力 の組成依存性 $\left(60^{\circ} \mathrm{C}\right)$

プロピレンとisot-ポリプロピレンの $\gamma-T$ 関係がー 本の直線に重なるという畑らの結果があり，また分岐 構造についてる, 直鎖ポリエチレンと分岥ポリエチレ ンの $\gamma-T$ 関係に大きな相違がないといら結果があ るが (いずれる北崎, 畑, 未発表), これらの点につ いてはもっと多くの例で精密な実験を重ねる必要があ る.

次に側鎖の長さが表面張力に及湾す影響の例とし て，ポリビニルアルコールの直鎖脂肪酸エステル（ポ

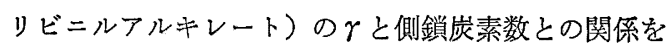
図2（黒丸）に示す10) $\gamma$ ははじめ減少して $\mathrm{C}_{8}$ で極 小となり，側鎖炭素数の増大とともに増大に転ずる. 同様の挙動は側鎖長の異なるポリメタクリレートのガ ラス転移温度飞ついても観察されて物り，增大の部分 はアルキル側鎖間の相互作用による．このことは界面 張力に関する Fowkes の式 (後述) を用いて求めら れた表面張力の分散力成分 $\left(\gamma^{d}\right)$ 之極性力成分 $\left(\gamma^{p}\right)$ の変化（図の白丸）を見ればいっそう明らかで，極小 点を経たあとの $\gamma$ の増大は $\gamma^{d}$ の寄与によっている. 同様の結果は, ジアルキル でも見いだされた11

共重合体では，低エネルギー成分の連鎖長が表面張 力に独特の影響を及汸す。たと党ばエチレン・プロピ レン ランダムの共重合体 (E-P 系) やテトラヒドロ フラン・プロピレンオキシド・ランダム共重合体 (THF -PO 系）では，低表面張力成分の モル分率 $x_{2}=0.4$ 付近から急激に減少して, 加成性を仮定した理論曲線

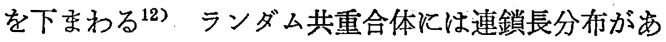
って，低ェネルギー成分のやや長い連鎖がモル分率 0.4 あたりから選択的に表面を覆うに足りるだけ十分 に存在するようになりこの選択性のためにとを低下 させるものと考觉られる.この考察の妥当性は, 連鎖
長を制御したブロック共重合体との比較で，いっそう 明確になる ${ }^{13)}$. 図 3 はエチレンオキシド プロピレン オキシド (EO-PO 系) のランダム共重合体とブロッ ク共重合体の $\gamma$ の組成依存性を示したものである. このプロック共重合体は $(\mathrm{EO})_{l}-(\mathrm{PO})_{m}-(\mathrm{EO})_{l}$ の構 造をもつもので, $m$ の数を $16,30,56$ と固定し, $x_{2}$ は $l$ の数で変化させたるのである. 図に見るように, ランダム共重合体は E-P 系や THF-PO 系と同じ傾 向を示すが，ブロック共重合体は低エネルギー成分で ある PO ブロックの導入によって $\gamma$ を急激汇減少さ せ，その連鎖長が大きい注ど減少の度合いも大きい。

非極性一極性モノマーの組み合わせであるェチンン。 酢酸ビニル共重合体の挙動はさらに特異で, ランダム 共重合体でも，䣷酸ビニル含量 $35 \mathrm{wt} \%$ 付近飞極小

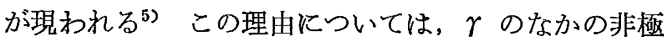
性成分 $\gamma^{d}$ の減少の仕方之，極性成分 $\gamma^{p}$ の增大の仕 方のかねあいによるといら現象論的解析も可能である が，野瀬 ${ }^{14)}$ の高分子液体論（空孔理論）に上れば酶酸 ビニル基の導入によってェネルギー項が増大するとと もに，エントロピー項も增大し，そのかねあいで極小 が現われる。

\section{3. 高分子固体の表面エネルギーの評価}

高分子固体の表面エネルギーは，直接測定すること ができず，間接的な評価法も確立しているとはいえな かった．とれが接着の界面化学的最適条件を議論する ことを困難にし，表面改質の技術をいつまでる経験的 な技術に終わらせていた大きな理由である.

そこで本章では，その評価法を中心にして述べる。 その方法として, ィルトの表面張力の 温度依存性 $(\gamma$ $\left.=E^{s}-S^{s} T\right)$ を利用して常温まで補外する方法や，液 状オリゴマーの常温付近での分子量依存性 $\left(\gamma=\gamma_{\infty}+\right.$ $A / M)$ を使って $M \rightarrow \infty$ 飞補外する方法があるが，こ こでは, 接触角 $\theta$ の測定による固体表面エネルギー の評価法に限る. その際, Young の式に現われる固 体表面張力 $\gamma_{S}$ を固体の表面エネルギーと同じものと し，両者を区別すべきであるという議論15),16) には立 ち入らない。

\section{3-1. Young の式をもとにした方法}

固体 $(S)$ の表面で接触角 $\theta$ を保って平衡に㐫る 液体 $(L)$ 飞対して, 次の Young の式が成り立つ $\left(\gamma_{S L}\right.$ は $S / L$ 間の界面張力, 添字 $V$ \&液体蒸気之の 平衡を意味する).

$$
\gamma_{S V}=\gamma_{S L}+\gamma_{L V} \cos \theta
$$

または $\gamma_{S}=\gamma_{S L}+\gamma_{L V} \cos \theta+\pi_{e}$

$$
\simeq \gamma_{S L}+\gamma_{L} \cos \theta
$$

$\pi_{e}=\gamma_{S}-\gamma_{S V}$ は表面圧と呼ばれるもので, 蒸気の収着 


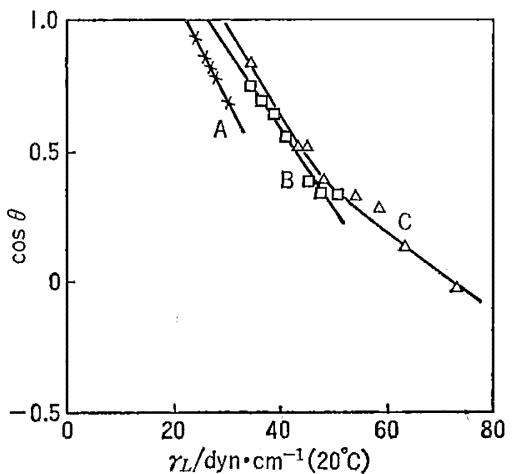

図 4 ポリミフッ化エチレンに対する Zisman プロット (A：非極性液体, B : 極性液体, $\mathrm{C}:$ 水素結合性液体)

による固体の表面エネルギーの低下を表わす，高分子 のような低エネルギー固体では $\pi_{e}$ を無視できるるの として $\gamma_{L V}$ す $\gamma_{L}$ と記す この Young の式 (9) をもとにして, 次の上うに $\gamma_{s}$ が求められる.

(a) 臨界表面張力 $\left(\gamma_{c}\right)$ の最大值 ${ }^{17)}$

一つの固体汇対する $\gamma_{L}-\cos \theta$ プロット（Zisman プロット) は，測定液体が非極性液体（A）であるか， 極性液体（B）で西るか，水素結合性液体（C）であ るがよって異なる直線を与光，したがって $\cos \theta=1$ への外插値 $\gamma_{C}$ (臨界表面張力) 女, $\gamma_{C}{ }^{\mathrm{A}}, \gamma_{C}{ }^{\mathrm{B}}, \gamma_{C} \mathrm{C}$ と異なる（図4)，そのららの最大值が $\gamma_{C}(\max ) \simeq \gamma_{S}$ である.なぜなら (9) 式で, $\cos \theta=1, \gamma_{L} \equiv \gamma_{C}$ ， そ のときの $\gamma_{S L}$ を $\gamma_{S L}$ とすると，

$$
\gamma_{C}=\gamma_{S}-\gamma_{S L} *
$$

固体 $(S)$ と液体 $(L)$ の組み合せたよっては $\gamma_{S L}{ }^{*} \rightarrow$ 0 となりうるので, そのとき $\gamma_{C} \rightarrow \gamma_{C}(\max ) \simeq \gamma_{S}$ であ る.

図4のような液体系列による不連続なプロットを嫌 らなら, ランダムに多数の液体で Zisman ブロットを 行ない,得られる点群の最右端を結ぶ直線によって $\gamma_{C}$ を求め，こ机を峌としてるよい，ただしこの場合 も，異なる系列 $\mathrm{A} ， \mathrm{~B} ， \mathrm{C}$ 嘱寸る液体をもれなく数

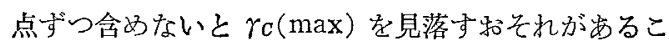
とに注意する。

Sell と Neumann ${ }^{18)}$ は $\cos \theta-\gamma_{L} \cos \theta$ プロット の $\cos \theta \rightarrow 1$ のときの $\gamma_{L} \cos \theta$ を臨界湿潤压 $\left(\beta_{C}\right)$ と 名付列 $\beta_{C} \simeq \gamma_{S}$ としたが，このプロットも夜体系 列 (A，B，C) 飞よって異なる曲線を与光，したがっ て異なる $\beta_{c}\left(\beta_{c^{\mathrm{A}}}, \beta_{c^{\mathrm{B}}}, \beta_{c} \mathrm{C}\right)$ を与兄る。矢のうちの 最大值 $\beta_{C}(\max ) \simeq \gamma_{S}$ である. 証明は上と同じで, 得 られる值も $\gamma_{C}(\max )$ 飞等しい。

(b) $\gamma_{L}-\gamma_{L} \cos \theta$ プロットに括ける $\gamma_{L} \cos \theta$ の 最大值 ${ }^{193}$

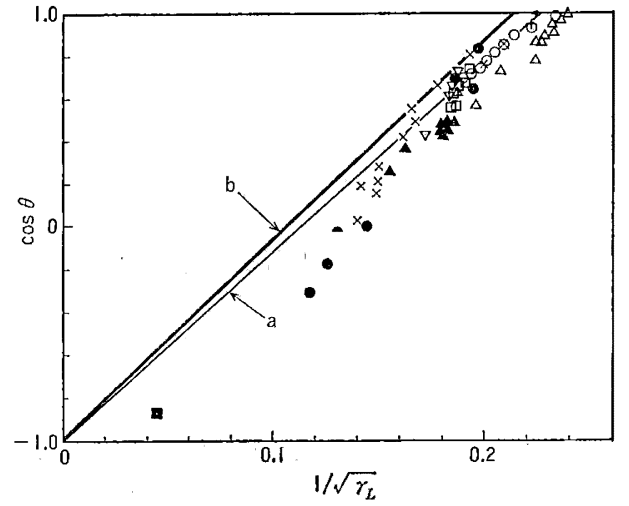

$\bigcirc$ : alkanes, $\nabla$ : alkylaryl compd., +di-n-alkyl ethers, $\mathbf{\Delta}$ : esters, : alcohols \& water soluble liquids, $\square$ : acids, $x$ : halogenated hydrocarbons, $\triangle$ : poly-siloxanes, $\mathbf{D}: \mathrm{Hg}$.

図 5 PTFE に対する $\cos \theta-1 / \sqrt{\gamma L}$ プロット

$\gamma_{L}$ に対して $\gamma_{L} \cos \theta$ をプロットすると，ある $\gamma_{L}$ で $\gamma_{L} \cos \theta$ は極大值をとる。（9)式を見机ばわかる上 うに, この值は $\gamma_{S L}=0$ 亿対応し $\gamma_{L} \cos \theta(\max ) \simeq \gamma_{S}$ である. Sell と Neumann るこのプロ,トを行なっ ているが，液体系列の選択注意していないので極大 值を見いだすことができなかったここでも $\mathrm{A} ， \mathrm{~B}$ ， C の液体系列のすべてを含めることが重要である.

\section{3-2. Good-Girifalco の式をもとにした方法}

界面張力 $\gamma_{12}$ 劣各相の表面張力 $\gamma_{1}, \gamma_{2}$ で表わそう とする試みの一つが，次の Good-Girifalco の式であ る20) (Ф は相互作用パラメーター).

$$
\gamma_{12}=\gamma_{1}+\gamma_{2}-2 \Phi \sqrt{\gamma_{1} \gamma_{2}}
$$

添字 $(1,2)$ を $(S, L)$ と書き直して Young 式と組 み合わせると

$$
\begin{aligned}
\gamma_{S} & =\frac{\left\{\gamma_{L}(1+\cos \theta)+\pi_{e}\right\}^{2}}{4 \Phi^{2} \gamma_{L}} \\
& \simeq \frac{\gamma_{L}(1+\cos \theta)^{2}}{4 \Phi^{2}}
\end{aligned}
$$

または

$$
\begin{aligned}
\cos \theta & =2 \Phi \sqrt{\frac{\gamma_{S}}{\gamma_{L}}}-1-\frac{\pi_{e}}{\gamma_{L}} \\
& \simeq 2 \Phi \sqrt{\frac{\gamma_{S}}{\gamma_{L}}}-1
\end{aligned}
$$

これらをもとにして，次に述べるようないくつかの $\gamma_{S}$ の評価法が提案された。

(a) Good-Girifalco の方法20c)

（12）※たは（13）式の すが適当な方法で決められ るならば，接触角の測定によって $\gamma_{S}$ を求めることが できる. Good らはガラス状炭化フッ素の $\gamma_{S}$ を求め るにあたって，その低分子同族体である液状炭化フッ 素 $\left(\gamma_{1}\right)$ のベンゼンと $\alpha$-メチルナフタレン $\left(\gamma_{2}\right)$ に対 する $\gamma_{12}$ を実測して，(11) 式によってそれぞれの 


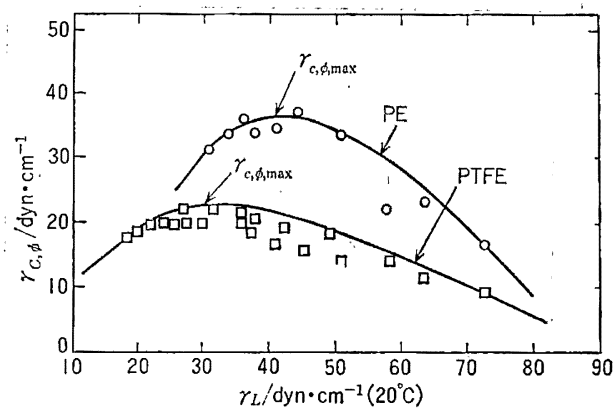

図 6 ポリエチレン (PE) とポリテトラフルオロエチレ ン (PTFE) に対する $\gamma_{C, \phi}-\gamma_{L}$ プロット (Wu)

を求め, 同じ二つの液体によるガラス状炭化フッ素の 接触角から（12）式によって $\gamma_{S}$ を求めて，それぞれ $23.0 \mathrm{dyn} \cdot \mathrm{cm}^{-1}$ と $21.8 \mathrm{dyn} \cdot \mathrm{cm}^{-1}$ (平均 $22.4 \mathrm{dyn}$. $\mathrm{cm}^{-1}$ ) を得た，これは液体炭化フッ素の $\gamma_{L}$ の実測值 $22.4 \mathrm{dyn} \cdot \mathrm{cm}^{-1}$ とよく一致する.

結晶性の同族体であるポリテトラフルオロエチレン (PTFE) については，Zisman らの接触角のデータを 用いて図 5 の上らに $\cos \theta-1 / \sqrt{\gamma_{L}}$ のプロットを行な う。この点群に共通な勾配（図のa）が (13) 式によ る $2 \Phi \sqrt{\gamma_{s}}$ である. Good らは PTFE の構造や極性 を考虑して $\Phi=0.80 \sim 0.85$ とすべきだとし，炎のと きこの勾配から $\gamma_{S}=26 \sim 30 \mathrm{dyn} \cdot \mathrm{cm}^{-1}$, 平均 $28 \mathrm{dyn}$. $\mathrm{cm}^{-1}$ を得た。無定形炭化フッ素との相違は PTFEの 結晶性によるとする。

（b）畑, 北崎の方法 ${ }^{19)}$

Good らの方法はパラメータ Фを別途汇評価しな ければならないという点で, 不便でもあり不確実です ある.

Фは一般に 0.5〜1.0 の間の値をとり, 極性の似た ものどらしでは 1 に近い，実際 Good らの式 (11) で $\gamma_{S L}=0$ (極性の似たものどうしの条件）と拈くと， $\Phi=\left(\gamma_{S}+\gamma_{L}\right) / 2 \sqrt{\gamma_{S} \gamma_{L}}$ となり, これは算術平均と幾 何平均の比で, $\gamma_{S}$ と $\gamma_{L}$ が大きく相違しない限り, ほとんど1に近い（たとえば $\gamma_{S}=36, \gamma_{L}=64$ でも $\Phi=1.04)$. 一つの固体とたくさんの液体の組み合わ せのなかには，このような条件を満たするのが每るは ずで, 図 5 のプロットでは $(-1,0)$ を通り最大勾配 $\left(\Phi_{\max }=1\right)$ をるつ直線 b がとれに相当する. したが ってその勾配 $2 \sqrt{\gamma_{S}}$ から（または $\cos \theta=1$ 飞打ける 横軸の切片 $1 \sqrt{\gamma_{L}}=1 \sqrt{\gamma_{S}}$ として), $\gamma_{S}$ が求められ る.このようにして得られたPTFEの $\gamma_{S}=22.0 \mathrm{dyn}$. $\mathrm{cm}^{-1}$ で, 無定形炭化フッ素の $\gamma_{S}$ 就よび他の方法で 得た $\gamma_{s}$ の值とよく一致する.

(c) Wu の方法 ${ }^{83,21)}$

Wu は臨界表面張力の定義 $\gamma_{C}=\lim _{\theta \rightarrow 0} \gamma_{L}$ を (12) 式
に入れて次式を導いた。

$$
\begin{aligned}
\gamma_{C, \phi} & \simeq \Phi^{2} \gamma_{S}-\pi_{e} \\
& \simeq \frac{\gamma_{L}(1+\cos \theta)^{2}}{4}
\end{aligned}
$$

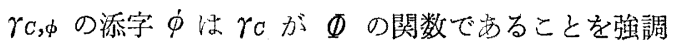
するためにつけられた. (15) 式による $\gamma_{C, \phi} を \gamma_{L}$ に 対してプロットして図 6 を得, その極大值 $\gamma_{C, \phi}(\max )$ を祙とした。この極大值は（14）式でい党ば， $\pi_{e}$ を

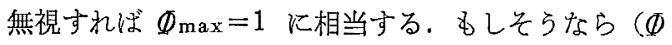
$=1$ を $\gamma_{s}$ を求める条件とするなら)，西克て (12) 式を $\gamma_{C}$ に変換するまであなく（12）式とのるのから

$$
\gamma_{S} \Phi^{2} \simeq \frac{\gamma_{L}(1+\cos \theta)^{2}}{4}
$$

この右辺（(15）式と同じである) を礼に対して プロットして，その極大值をとれば，それが $\Phi=1$ に 相当し $\gamma_{S}$ を与兄る. Wu は 3-1. (a) で述べた， われわれのアイディア $\left(\gamma_{C}(\max ) \simeq \gamma_{s}\right)$ にとらわれ て，奇り道をしたようである.

\section{3-3. 拡張 Fowkes 式をむとにした方法}

各相の表面張力を分散力成分 $\left(\gamma^{d}\right)$ 之極性力成分 $\left(\gamma^{p}\right)$ の和として, Fowkes は界面張力 $\gamma_{12}$ に対して 次式を与光た。

$$
\gamma_{12}=\gamma_{1}+\gamma_{2}-2 \sqrt{r_{1}^{d} \gamma_{2}^{d}}
$$

これに対して次の 3 種の搪張式が提案されている.

(1) Owens $5^{22)}$, Kaelble $5^{23)}$

$$
r_{12}=\gamma_{1}+\gamma_{2}-2 \sqrt{{\gamma_{1}^{d} \gamma_{2}^{d}}_{1}}-2 \sqrt{\gamma_{1}^{p} \gamma_{2}^{p}}
$$

（2）北崎, 烟 ${ }^{5), 24)}\left(\gamma=\gamma^{a}+\gamma^{b}+\gamma^{c}\right)$

$$
\begin{aligned}
\gamma_{12} & =\gamma_{1}+\gamma_{2} \\
& -2 \sqrt{\gamma_{1}^{a} \gamma_{2}^{a}}-2 \sqrt{\gamma_{1}^{b} \gamma_{2}^{b}}-2 \sqrt{\gamma_{1}{ }^{c} \gamma_{2}{ }^{c}}
\end{aligned}
$$

(3) $\mathrm{Wu}^{25)}$

$$
\gamma_{12}=\gamma_{1}+\gamma_{2}-\frac{4 \gamma_{1}^{d} \gamma_{2}^{d}}{\gamma_{1}^{d}+\gamma_{2}^{d}}-\frac{4 \gamma_{1}^{p} \gamma_{2}^{p}}{\gamma_{1}^{p}+\gamma_{2}^{p}}
$$

一方，接着仕事 $W_{a}$ は

$$
W_{a}=\gamma_{1}+\gamma_{2}-r_{12}=r_{2}(1+\cos \theta)
$$

各式の添字 $(1,2)$ を $(S, L)$ と書き直して (21) 式 と組み合わせると，たとえば北崎，烟らの式では

$$
\begin{aligned}
& \gamma_{L}(1+\cos \theta) \\
& \quad=2 \sqrt{\gamma_{S^{a} \gamma_{L}^{\mathrm{a}}}}+2 \sqrt{\gamma_{S^{\mathrm{b}} \gamma_{L}^{\mathrm{b}}}}+2 / \sqrt{\gamma_{S^{\mathrm{c}}} \gamma_{L}^{\mathrm{c}}}
\end{aligned}
$$

成分 $\left(\gamma_{L^{\mathrm{a}}}, \gamma_{L^{\mathrm{b}}}^{\mathrm{b}}, \gamma_{L^{\mathrm{c}}}\right)$ のわかった 3 種以上 (Kaelble や Wu の式では 2 種以上）の液体で接触角を測 定し， $\gamma_{s}^{\mathrm{a}}, \gamma_{s^{\mathrm{b}}}^{\mathrm{b}}, \gamma_{s^{\mathrm{c}}}$ 未知数として求めれば，その 和として $\gamma_{S}$ が得られる ${ }^{26)}$

\section{3-4. 二液法と $\pi_{e}$ の問題}

今まで述べてきた諸法は高分子物質のような低ェネ ルギー固体には適しているが，金属やセラミックスの ような高ェネルギー固体では, 普通の有機夜体は自発 高分子 32 巻 9 月号 (1983 年) 
的にひろがって液滴を作らないといら困難がある、し かしこのような固体でも，たと党ば岸化水素液体中で は水のような非相溶液体によって液滴を作ることがで き，接触角を測ることができる．玉井27)はこの二液法 で高ェネルギー固体の表面エネルギーを評価する方法 を開発した．この方法では前述（9）式で省略した表 面圧 $\pi_{e}$ は現われず，したがってその省略による誤差 を心配する必要がない，しかし，浸漬液の吸着による 表面污染といら新しい問題が佂こる.

一液法で $\pi_{e}$ が省略できるかどらかについては, 蒸 気圧を变えても高分子固体付対する接触角は変わらな いといらZismanの実験的証明もあるが，まだ問題 が残っている.この量は熱力学的に吸着実験から, 次 式を用いて求めることができる（ $\Gamma:$ 吸着量, $p$ : 蒸 気任)

$$
\pi_{e}=R T \int_{0}^{p} \Gamma d \ln p
$$

Zettlemoyer ${ }^{28)}$ がラフロンに対するへキサンの吸着 から得た值は $\pi_{e}=5.7 \mathrm{dyn} \cdot \mathrm{cm}^{-1}$ と達した。 $\pi_{e}$ の問 題は，一液法では，な和検討を必要とする課題であ る.

\section{4. あとがき}

高分子液体の表面張力理論（統計熱力学理論）飞触 れることができなかったばかりでなく、メルトの表面 張力ではとの温度依存性（したがって表面エネルギー と表面エントロピー）という基本的な性質について述 ベる余裕がなかった．また，代表的なポリマーの $\gamma_{S}$ を表示することが親切だと思われたが，文献》济譲っ た。

本稿では触れなかったが高分子メルト間の界面張 力, 高分子溶液と非相溶性溶剂との間の界面張力, 特 よび高分子溶液の相分離界面の諸問題が，理論的飞も 実験的にも発展して興味ある話題を提供している。こ れらについては別の機会を待ちたい。

\section{文献}

1) S. Wu: I. Macromol. Sci., C 10, 1 (1974)

2) S. Wu: Polymer Blends, Vol. 1, ed. D. R. Paul and S. Newman, Academic Press (1978) p. 243

3) S. Wu: Polymer Interface and Adhesion, Marcel Dekker (1982)
4) 畑 敏雄: 高分子実験学 12 熱力学的. 電気的お よび光学的珄質, 高分子学会編, 共立出版（近刊 予定）

5）畑 敏雄：高分子, 17, 594 (1968); 表面, 6, 281 (1968)

6) T. Hata, T. Kasemura: Adhesion and Adsorption of Polymers, Part A, ed. L. - H. Lee, Plenum (1980) p. 15

7) D. G. LeGrand, G. L. Gaines, Jr. : I. Colloid Interface Sci., 31, 162 (1969)

8) D. G. LeGrand, G.L. Gaines, Jr. : ibid., 51, 338 (1975)

9) 紬村知之：学位論文（東京工業大学, 1981)

10）紬村知之, 宇治文雄, 近土隆, 畑 敏雄: 高分 子論文集, 36, 337 (1979)

11) 紬村知之, 山下典男, 近土隆, 畑敏雄: 同上, 33, 703 (1976)

12）紬村知之, 山下典男, 鈴木克己, 近土 隆, 畑 敏雄：同上, 35, 263 (1978)

13) 紬村知之, 山下典男, 宇治文雄, 近土隆, 畑 敏雄 : 同上, 35, 779 (1978)

14) T. Nose: Polymer, J., 3, 196 (1972)

15) A.W. Adamson: Physical Chemistry of Surface, Interscience (1960) p. 235

16）小野 周: 表面張力, 共立出版 (1980) p. 86

17) 北崎寧昭, 畑 敏雄: 接着協会誌, 8, 123 (1972)

18) (a) O. Drieger, A.W. Neumann, P.J. Sell: Kolloid, Z.u.Z. Polymere, 201, 52 (1965); (b) P.J. Sell, A.W. Neumann: Angew. Chem. 78, 321 (1966)

19）畑敏雄, 北崎寧昭: 緎維学会昭和 56 年年次大 会講演要旨集, p. 147 (1981)

20) (a) L. A. Girifalco, R. J. Good: I. Phys. Chem., 61, 904 (1957), (b) R. J. Good, L. A. Girifalco, G. Kraus: ibid., 62, 1418 (1958), (c) R. J. Good, L. A. Girifalco: ibid., 64, 561 (1960)

21) S. Wu: Adhesion and Adsorption of Polymers, Part A, ed. L. -H. Lee, Plenum (1980) p. 53

22) D. K. Owens, R. C. Wendt: I. Appl. Polym. Sci., 13, 1741 (1969); ibid., 14, 1725 (1970)

23) D. H. Kaelble, K.C. Uy: I. Adhesion, 2, 50 (1970)

24）北崎寧炤, 畑 敏雄 : 接着势会誌, 8, 131 (1972)

25) S. Wu: I. Phys. Chem., C 34, 19 (1971); I. Adhesion, 5, 39 (1970)

26) 北崎寧昭, 畑 敏雄 : 接着協会誌, 8, 178 (1972)

27) Y. Tamai, M. Makuuchi, M. Suzuki: J. Phy. Chem., 71, 4176 (1967)

28) A.C. Zettlemoyer: I. Colloid Interface Sci., 28, 343 (1968) 